\title{
Cholinergic Regulation of Neurite Outgrowth from Isolated Chick Sympathetic Neurons in Culture
}

\author{
David H. Small, ${ }^{1}$ Gullveig Reed, ${ }^{1}$ Bryony Whitefield, ${ }^{1}$ and Victor Nurcombe ${ }^{2}$ \\ Departments of ${ }^{1}$ Pathology and ${ }^{2}$ Anatomy and Cell Biology, The University of Melbourne, and the Mental Health Research \\ Institute of Victoria, Parkville, Victoria 3052, Australia
}

\begin{abstract}
Neurotransmitters have been reported to regulate neurite outgrowth in several vertebrate and nonvertebrate species. In this study, cultures of isolated embryonic day 12 (E12) chick sympathetic neurons were grown in the presence of cholinergic receptor agonists or antagonists. Both $\mathrm{ACh}$ and the nonhydrolyzable cholinergic agonist carbamylcholine (CCh) inhibited neurite outgrowth. ACh (0.1-1.0 mM) decreased the percentage of neurons bearing neurites, but had no significant effect on cell survival. The effect of ACh was increased in the presence of the cholinesterase inhibitors BW284C51 $(1 \mu \mathrm{M})$, Tacrine $(20 \mu \mathrm{M})$, and edrophonium (200 $\mu \mathrm{M})$. Neurite outgrowth was strongly inhibited by the muscarinic receptor agonist oxotremorine (5-100 $\mu \mathrm{M})$ and weakly inhibited by nicotine (50 $\mathrm{nm}$ to $10 \mu \mathrm{M}$ ). The inhibitory effect of $\mathrm{CCh}$ was decreased by the muscarinic receptor antagonist atropine $(10 \mu \mathrm{M})$, demonstrating that the effect of $\mathrm{CCh}$ on neurite outgrowth was mediated, at least in part, through a muscarinic receptor. The possibility that AChE can influence neurite outgrowth directly, through a noncatalytic mechanism, was also examined. When dissociated chick brain or sympathetic neurons were grown on plates precoated with purified AChE, neurite outgrowth was strongly stimulated. However, the neurite outgrowth-promoting effect of AChE was strictly dependent upon the presence of substratumbound heparan sulfate proteoglycans (HSPG). Pretreatment of AChE with diisopropylfluorophosphate to inhibit the esterase activity did not abolish this effect, suggesting that the neurite outgrowth-promoting effect of AChE was associated with a noncatalytic mechanism, a view supported by the observation that soluble AChE had no effect on neurite outgrowth. The finding that cholinergic agents influence neurite outgrowth from sympathetic neurons provides further evidence that neurotransmitters may influence cytoarchitecture and may explain the expression of AChE in association with neurite outgrowth.
\end{abstract}

[Key words: cholinesterase, chick, development, sympathetic, Alzheimer's disease, amyloid, adhesion]

There is increasing evidence that neurotransmitters have nonclassical actions in the regulation of processes associated with neuronal differentiation (Lauder, 1993). For example, gluta-

Received Mar. 14, 1994; revised June 3, 1994; accepted June 8, 1994.

-This work was supported by grants to D.H.S. from the National Health and Medical Research Council of Australia.

Correspondence should be addressed to Dr. David H. Small, Department of Pathology, University of Melbourne, Parkville, Victoria 3052, Australia.

Copyright (C) 1995 Society for Neuroscience $0270-6474 / 95 / 150144-08 \$ 05.00 / 0$ mate, serotonin, and dopamine have all been shown to influence neurite outgrowth in culture (Mattson, 1988; Lipton and Kater, 1989). There is also evidence that ACh could have nonclassical actions in the nervous system (Lankford et al., 1988; Lipton et al., 1988; Mattson, 1988). The biosynthetic and degradative enzymes of cholinergic pathways $\mathrm{ChAT}$ and $\mathrm{AChE}$ are expressed in the developing brain well before the major period of synaptogenesis (Filogamo and Marchisio, 1971; Silver, 1974), suggesting that they may be involved in functions unrelated to neurotransmission. ACh has been shown to suppress neurite outgrowth from chick (Lankford et al., 1988) and rat (Lipton et al., 1988) retinal cells, from hippocampal pyramidal neurons (Mattson, 1988) and to prevent the inhibition of process outgrowth by 5-HT on Helisoma neurons (McCobb et al., 1988).

Studies by Layer and coworkers (Layer et al., 1988, 1992; Layer, 1991; Layer and Kaulich, 1991), Robertson and coworkers (Kobertson, 1987; Robertson et al., 1988; Robertson and $\mathrm{Yu}, 1993$ ) and Small et al. (1992) have demonstrated that the cxpression of $\mathrm{AChE}$ during early development correlates closely with the major phase of neurite outgrowth. The subcellular localization of $\mathrm{AChE}$ is also consistent with a role in neurite outgrowth. For example, in chick sympathetic neurons, AChE is associated with the lamellipodia and filopodia of growth cones (Rotundo and Carbonetto, 1987). The amino acid sequence homology between $\mathrm{AChE}$ and two Drosophila cell adhesion proteins, glutactin and neurotactin, indicates that AChE might have a role in cell adhesion. Studies using inhibitors of $\mathrm{AChE}$ activity suggest that AChE may regulate neurite outgrowth through a noncatalytic mechanism (Layer et al., 1993).

The observed association of AChE with neurites of sympathetic neurons has prompted us to examine the effect of cholinergic agonists and antagonists, as well as AChE inhibitors on the neurite outgrowth from isolated chick sympathetic neurons in vitro. We provide evidence that $\mathrm{AChE}$ can inactivate the neurite outgrowth-inhibiting actions of $\mathrm{ACh}$. In addition, $\mathrm{AChE}$ can stimulate neurite outgrowth through an adhesion mechanism, at least as potently as that of the highly adhesive molecule laminin.

\section{Materials and Methods}

Materials. Fetal bovine serum for cell culture was obtained from Commonwealth Serum Laboratories (Parkville, Australia). Fetal bovine serum for the purification of $\mathrm{AChE}$ was obtained from a local abattoir. Dulbecco's modified Eagle's medium (DMEM) and GMS-X growth supplement were from GIBCO-Bethesda Research Labs (Grand Island, NY). Laminin (purified from mouse EHS tumor) was obtained from Collaborative Research (Bedford, MA). Oxotremorine sesquifumarate was purchased from ICN Biomedicals (Seven Hills, Australia). Carbamylcholine chloride, acetylcholine chloride, nicotine (free base), 

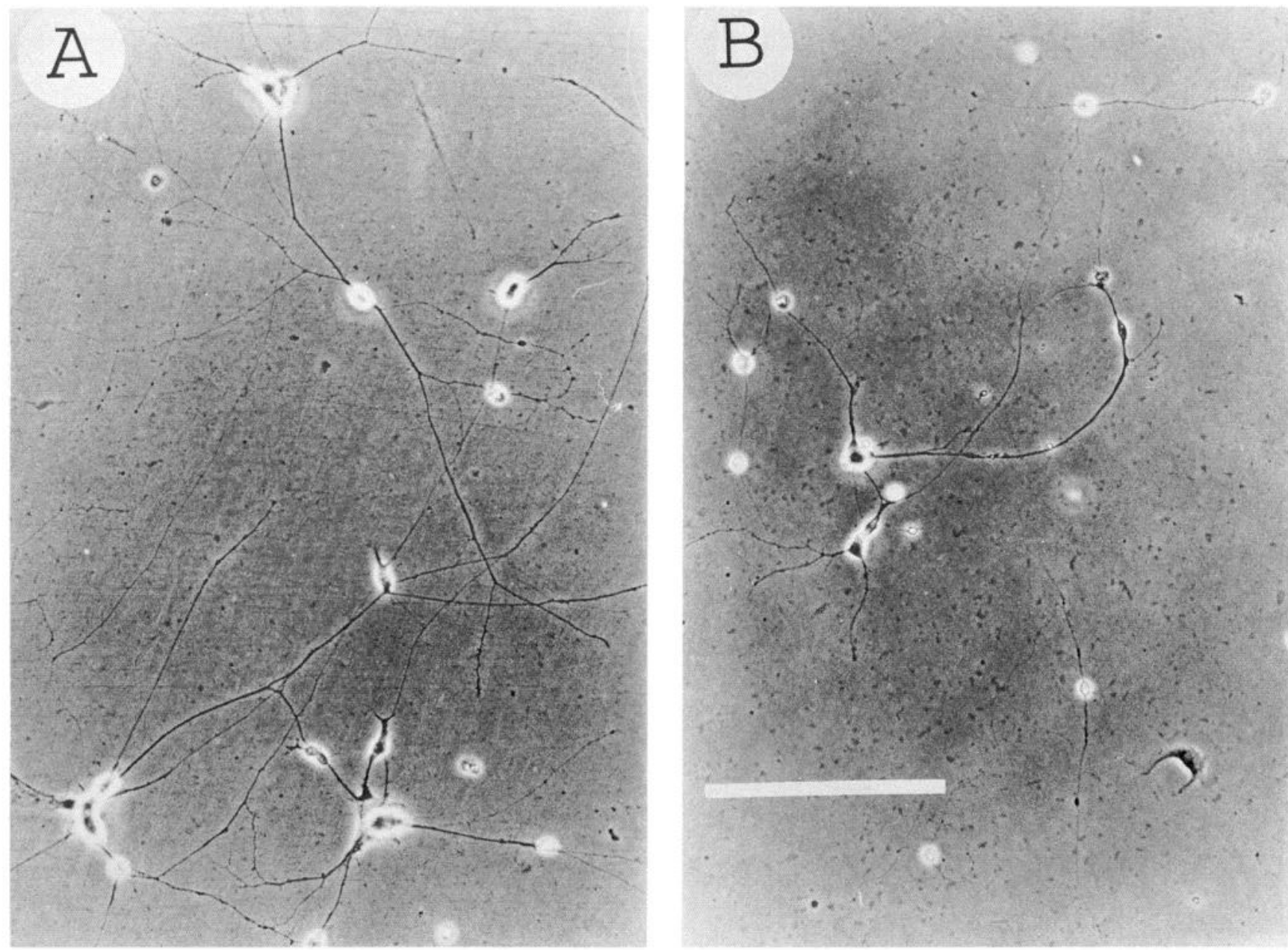

Figure 1. Phase-contrast micrograph of E12 chick sympathetic neurons cultured for $24 \mathrm{hr}$ in serum-free DMEM. The cells were cultured in the absence $(A)$ or presence $(B)$ of $1 \mathrm{~mm}$ CCh for $24 \mathrm{hr}$ after plating. Scale bar, $100 \mu \mathrm{m}$.

atropine (free base), mecamylamine hydrochloride, diisopropylfluorophosphate (DFP), edrophonium chloride, 1,5-bis(4-allyldimethylammoniumphenyl)pentan-3-one dibromide (BW284C51), nerve growth factor (NGF, 2.5S), putrescine, prostaglandin F2 $\alpha$, progesterone and poly-L-lysine were purchased from Sigma Chemical Co. (St. Louis, MO).

Purification of AChE and HSPG. AChE was purified from fetal bovine serum using a previously published procedure involving affinity chromatography on edrophonium-Sepharose, followed by size-exclusion and ion-exchange high-performance liquid chromatography (HPLC) (Michaelson and Small, 1993). The purified enzyme possessed a specific activity of approximately $1000-3000$ units $/ \mathrm{mg}$ protein and was greater than $99 \%$ pure as assessed on silver-stained native and denaturing polyacrylamide gels and was more than $90 \%$ pure as assessed by N-termina amino acid sequencing. Heparan sulfate proteoglycans (HSPG) were purified from the conditioned medium of cultures of postnatal day 3 (P3) mouse brain cells as previously described (Small et al., 1994).

Immunoaffinity purification of AChE. Protein-A-Sepharose (PAS; Pharmacia-LKB, Uppsala, Sweden) was suspended in phosphate-buffered saline (PBS), and $0.2 \mathrm{ml}$ aliquots of the swollen gel were washed extensively with an additional $10 \mathrm{ml}$ of PBS. Each aliquot was incubated for $24 \mathrm{hr}$ at $4^{\circ} \mathrm{C}$ with $200 \mu \mathrm{l}$ of an anti-AChE monoclonal antibody (clone AE 1; IgG1 ascites from Chemicon International, Temecula, CA) or $200 \mu \mathrm{l}$ of a control anti-neurofilament monoclonal antibody (clone NN18; IgG1 ascites from Sigma Chemical Co., St. Louis, MO). The gel from each incubation mixture was washed four times with $5 \mathrm{ml}$ of PBS and then $1 \mathrm{ml}$ of AChE ( 20 units $/ \mathrm{ml}$ in PBS) purified by edrophoniumSepharose chromatography and size-exclusion and ion exchange HPLC (Michaelson and Small, 1993) was added to each batch of gel and incubated at $4^{\circ} \mathrm{C}$ for $16 \mathrm{hr}$. Each incubation mixture was then poured into polypropylene Econocolumns (Bio-Rad Laboratories, Richmond, CA) and each column was washed with $15 \mathrm{ml}$ of PBS. The columns were eluted with $1.0 \mathrm{ml}$ of $3.5 \mathrm{M} \mathrm{MgCl}_{2}$ in $10 \mathrm{~mm}$ sodium phosphate buffer, $\mathrm{pH}$ 7.4. The eluted protein was dialyzed and against PBS by centrifugation through CF25 filter cones (Amicon, Danvers, MA).

Treatment and analysis of $A C h E$. AChE activity was assayed by the method of Ellman et al. (1961). One unit of activity was defined as the number of micromoles of acetylthiocholine hydrolyzed per minute at $30^{\circ} \mathrm{C}$. The protein concentration of purified AChE was calculated on the basis of an $\epsilon^{\mathrm{mg} / \mathrm{ml}}$ of 1.10 at $280 \mathrm{~nm}$ (Ralston et al., 1985). For the inactivation of $\mathrm{AChE}$ by diisopropylfluorophosphate (DFP), the enzyme $(0.01 \mathrm{mg} / \mathrm{ml})$ was incubated with $0.15 \mathrm{~mm}$ DFP (approximately 1000 fold excess over the number of active sites) in PBS for $30 \mathrm{~min}$ at room temperature. This treatment inactivated $>99 \%$ of the AChE activity.

Cell culture. Sympathetic ganglia were dissected from $12 \mathrm{~d}$ old chick embryos (E12) and the tissue dissociated and neurons plated in 24-well culture plates at a density of 3000 cells/well as previously described (Small et al., 1994), with the exception that all cultures were grown in serum-free DMEM containing $0.01 \%$ (v/v) GMS-X growth supplement, $100 \mu \mathrm{M}$ putrescine, $1.67 \mu \mathrm{g} / \mathrm{ml}$ prostaglandin $\mathrm{F} 2 \alpha, 6.67 \mathrm{ng} / \mathrm{ml}$ progesterone, and $5 \mathrm{ng} / \mathrm{ml} \mathrm{NGF}$. For studies on the effect of AChE on central neurons, E1 2 chick brains were dissected and the cerebral hemispheres minced finely and digested with trypsin as previously described (Small et al., 1992). Cells were cultured in 24-well plates at a density of 10,000 cells/well in DMEM containing 10\% fetal calf serum.

To test the effect of substratum-bound proteins on neurite outgrowth, the wells of culture dishes were coated with different proteins by incubating with the protein of interest made up in PBS or borate buffer at room temperature. The order of application of each protein was first 


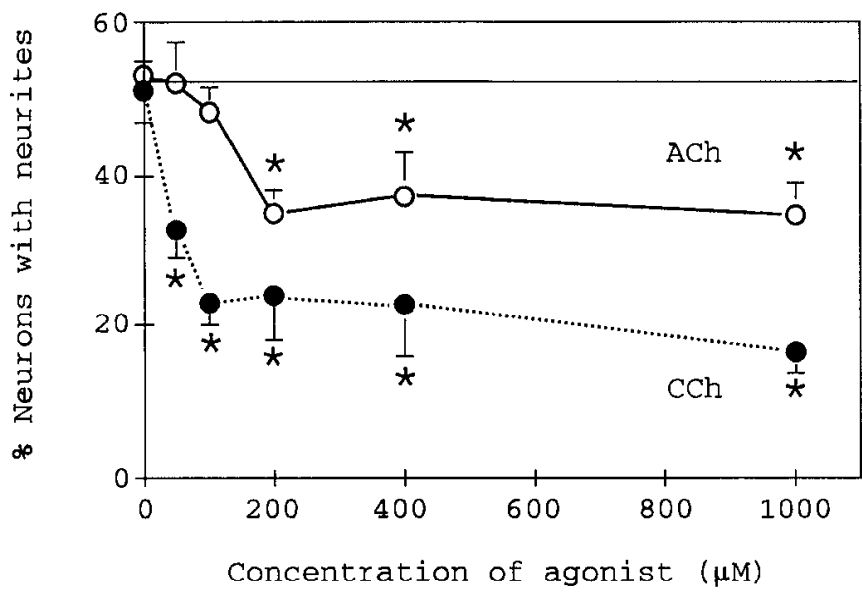

Figure 2. Quantitative image-capture analysis of representative neurite outgrowth from E1 2 chick sympathetic neurons maintained in culture for $24 \mathrm{hr}$. Figure shows the percentage of neurons bearing neurites as a function of the concentration of $\mathrm{ACh}$ or $\mathrm{CCh}$ added to the culture medium. Data are expressed as the mean value ( \pm SEM) oblained from four culture wells in which the percentage of cells bearing neurites greater than $20 \mu \mathrm{m}$ was determined. Five fields per well, each field containing approximately 20 neurons, were counted. ${ }^{*}$, points representing mean values that were significantly different from the corresponding control value for $0 \mu \mathrm{M} \mathrm{CCh}$ or $\mathrm{ACh}(P<0.05)$.

polylysine $(0.1 \mathrm{mg} / \mathrm{ml}$ in $15 \mathrm{~mm} \mathrm{Na}$-borate buffer, $\mathrm{pH} 8.4)$ for $30 \mathrm{~min}$ then P3 HSPG or laminin $(10 \mu \mathrm{g} / \mathrm{ml})$ for $2 \mathrm{hr}$, and then AChE $(10 \mu \mathrm{g} /$ $\mathrm{ml})$ for $2 \mathrm{hr}$. After incubation each well was washed three times with PBS immediately before being used as a substrate for cell growth.

Measurement of neurite outgrowth. Cultures were examined $24 \mathrm{hr}$ after plating under phase-contrast microscopy and selected fields captured for computer-assisted image analysis (MD30 Plus Image analysis system, Adelaide, Australia). The percentage of surviving cells extending neurites longer than $20 \mu \mathrm{m}$ in five fields of each well was measured. Approximately 100 cells were counted in each well. For the analysis of neurite length, the longest neurite on 20 neurons bearing neurites in each well was measured. A minimum of four wells for each treatment group was analyzed.

Statistical analysis. Differences between the means of controls and each treatment groups were analyzed by a two-tailed Student's $t$ test. For the comparison of multiple treatment groups, data were also analyzed using a onc-way or two-way analysis of variance (ANOVA). The significance of differences between two treatment groups in experiments involving multiple treatments was assessed using a Tukey test for multiple comparisons. Means were assumed to be significantly different when the $P$ value for the null hypothesis was less than 0.05 .

\section{Results}

\section{Effect of $A C h$ and $C \mathrm{C} h$ on neurite outgrowth}

We first examined the possibility that $\mathrm{ACh}$ influences the growth of neurites in cultures of E12 chick sympathetic neurons. Sympathetic ganglia were dissected from E12 chicks and the tissue digested with trypsin. Cell preparations were plated in 24-well culture dishes precoated with polylysine and laminin and cultured in the presence of various concentrations of $\mathrm{ACh}$ or $\mathrm{CCh}$ in serum-free medium. After $24 \mathrm{hr}$ in culture, the neurons were visualized under phase-contrast microscopy (Fig. 1). The extent of neurite outgrowth was quantified by computer-assisted image analysis (Fig. 2). Neuronal survival in the NGF-containing medium on laminin substrates was never less than $75 \%$ of the numbers originally plated.

The presence of $50 \mu \mathrm{M}$ to $1 \mathrm{~mm} \mathrm{CCh}$ or $200 \mu \mathrm{M}$ to $1 \mathrm{~mm} \mathrm{ACh}$ in the culture medium significantly decreased the percentage of neurons bearing neurites (Fig. 2). Similar results were obtained

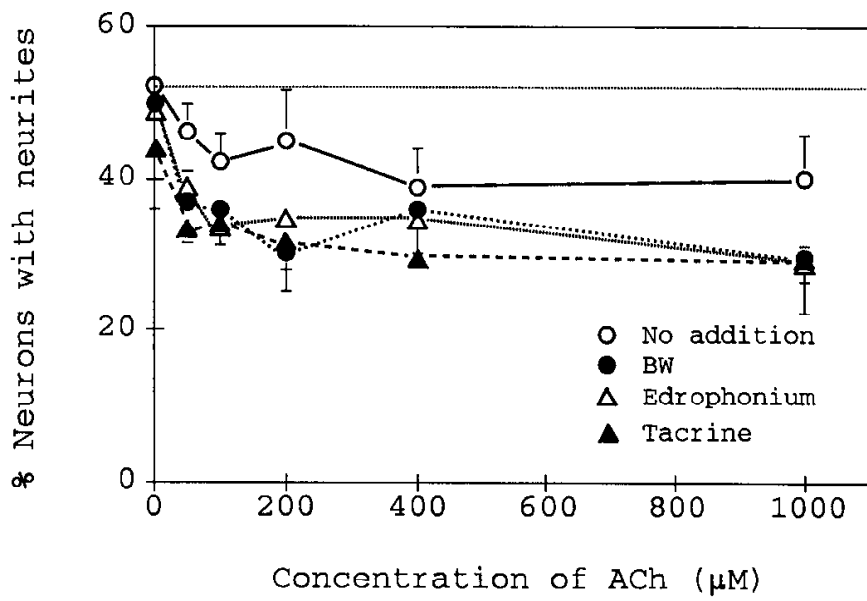

Figure 3. Effect of $\mathrm{ACh}$ and $\mathrm{AChE}$ inhibitors on neurite outgrowth from chick sympathetic neurons. Figurc shows the percentage of neurons bearing neurites as a function of the concentration of $\mathrm{ACh}$ in the presence or absence of AChE inhibitors $1 \mu \mathrm{M}$ BW284C51 $(B W), 200 \mu \mathrm{M}$ edrophonium, and $20 \mu \mathrm{M}$ Tacrine. Data are expressed as the mean value ( \pm SEM) obtained from four culture wells in which the percentage of cells bearing neurites greater than $20 \mu \mathrm{m}$ was determined. No addition, no AChE inhibitor added.

in three additional experiments. Neither $\mathrm{CCh}$ nor $\mathrm{ACh}$ significantly inhibited cell survival (data not shown). $\mathrm{CCh}$ was more potent than $\mathrm{ACh}$ in its ability to inhibit neurite outgrowth, both as seen in the minimum concentration required to produce a statistically significant effect (50 $\mu_{\mathrm{M}}$ for CCh vs $200 \mu \mathrm{M}$ for ACh) and in the degree of inhibition of neurite outgrowth. $\mathrm{ACh}(1$ $\mathrm{mm}$ ) decreased the percentage of neurons bearing neurites by approximately $35 \%$, whereas CCh (1 mM) decreased the percentage by approximately $65 \%$.

As CCh cannot be hydrolyzed by AChE, the difference in potency between CCh and ACh may have been due to the presence of endogenous AChE. To test this idea, the effect of ACh on neurite outgrowth in the presence of three $\mathrm{AChE}$ inhibitors (BW, edrophonium, Tacrine) was examined. The concentrations of all three inhibitors were chosen to inhibit $>99 \%$ of $\mathrm{AChE}$ activity in the cultures on the basis of their previously calculated inhibitor potencies (data not shown). All of the inhibitors significantly $(P<0.05$, two-way ANOVA) increased the potency of ACh (Fig. 3). Several other indices of the extent of neurite outgrowth (neurites per neuron, neurite length) were also analyzed (Table 1). Treatment with $1 \mathrm{~mm} \mathrm{ACh}$ or $200 \mu \mathrm{M}$ edrophonium did not significantly alter the number of neurites per neuron. However, the neurite length and the percentage of neurons with neurites were significantly decreased by treatment with either ACh or edrophonium. The most potent inhibition of neurite outgrowth was seen in cultures incubated with both $\mathrm{ACh}$ and edrophonium (Table 1).

\section{Effect of cholinergic receptor agonists and antagonists}

To define the class of cholinergic receptors that might mediate the actions of ACh and CCh on neurite outgrowth, the effect of cholinergic receptor agonists and antagonists was examined. Sympathetic neurons were cultured in the serum-free medium containing either nicotine (nicotinic receptor agonist), oxotremorine (muscarinic receptor agonist), or CCh (mixed muscarinic and nicotinic receptor agonist). The concentrations of each drug were chosen on the basis of their pharmacologic potencies 
Table 1. Effects of ACh and edrophonium on various parameters of neurite outgrowth

\begin{tabular}{llll} 
& Neurites/ & $\begin{array}{l}\text { Neurite } \\
\text { length }(\mu \mathrm{m} ; \\
n=20)\end{array}$ & $\begin{array}{l}\text { \% Neu- } \\
\text { rons } \\
\text { with } \\
\text { neurites } \\
(n=20)\end{array}$ \\
Treatment & $1.80 \pm 0.17$ & $1670 \pm 140$ & $60 \pm 4$ \\
\hline No addition & $1.70 \pm 0.18$ & $1230 \pm 110^{*}$ & $34 \pm 1^{*}$ \\
ACh $(1 \mathrm{mM})$ & $1.67 \pm 0.17$ & $1250 \pm 120^{*}$ & $49 \pm 2^{*}$ \\
Edrophonium $(200 \mu \mathrm{M})$ & $1.65 \pm 0.15$ & $890 \pm 100^{*}$ & $28 \pm 1^{*}$
\end{tabular}

E12 chick sympathetic neurons were plated at a density of 3000 cells/well and cultured for $24 \mathrm{hr}$ in serum-free medium in 24-well plates coated with $0.1 \mathrm{mg}$ / $\mathrm{ml}$ polylysine and $10 \mu \mathrm{g} / \mathrm{ml}$ laminin. Values are means \pm SEM of data obtained from four culture wells per treatment group. For the calculation of percentage of neurons with neurites, approximately 100 randomly selected neurons were counted in each of four wells. For the other two parameters, $n$ refers to the total number of neurons counted in each well. The number of neurites/neuron was calculated for all neurons in the field.

(Hadházy and Szerb, 1977; Birdsall et al., 1978; Small et al., 1993). Consistent with the results obtained in previous experiments, $\mathrm{CCh}(1 \mathrm{~mm})$ inhibited the percentage of neurons bearing neurites approximately $45 \%$ (Fig. 4). Nicotine $(0.5-10 \mu \mathrm{M})$ more weakly inhibited neurite outgrowth up to $30 \%$ at the highest concentrations, whereas oxotremorine $(5-100 \mu \mathrm{M})$ was more potent, inhibiting neurite outgrowth up to $80 \%$. Higher concentrations of nicotine (above $10 \mu \mathrm{M}$ ) did not cause any further inhibition of neurite outgrowth.

The ability of cholinergic receptor antagonists to block the action of $\mathrm{CCh}$ on neurite outgrowth was also examined. In the presence of the muscarinic receptor antagonist atropine $(10 \mu \mathrm{M})$, CCh did not significantly inhibit neurite outgrowth (Fig. 5). Although the mean value of percentage of neurons with neurites for incubations with $\mathrm{CCh}$ and the nicotinic receptor antagonist mecamylamine $(10 \mu \mathrm{M})$. was often greater than for $\mathrm{CCh}$ alone, the difference was never found to be statistically significant.

\section{Effect of $A C h E$ on neurite outgrowth}

As there was evidence from the studies of Layer et al. (1993) that AChE may stimulate neurite outgrowth through a noncatalytic mechanism, the effect of exogenously added $\Lambda \mathrm{ChE}$ on neurite outgrowth was examined. As AChE is known to associate with basement membrane heparan sulfate proteoglycans (HSPG) (Ramirez et al., 1990), we examined the effect of precoating culture dishes with HPLC-purified AChE and HSPG on the extent of neurite outgrowth from E12 chick sympathetic neurons. When neurons were cultured on substrates of polylysine and either AChE or HSPG, there was no observed increase in either the percentage of neurons with neurites (Fig. $6 A$ ) or neurite length (Fig. 6B). However, those cultures grown on polylysine with AChE and HSPG exhibited a marked increase in both parameters of neurite outgrowth. The stimulation of neurite outgrowth achieved was comparable to that of laminin alone. The catalytic activity of AChE was found not to be essential for this effect as AChE incubated with a 1000-fold excess of the irreversible esterase inhibitor DFP (to inactivate the AChE) also stimulated neurite outgrowth when added in combination with HSPG. Soluble AChE and HSPG ( $1 \mu \mathrm{g}$ of each per well, an amount well in excess of the amount bound to the plates in the previous experiments) failed to stimulate neurite outgrowth over control levels.

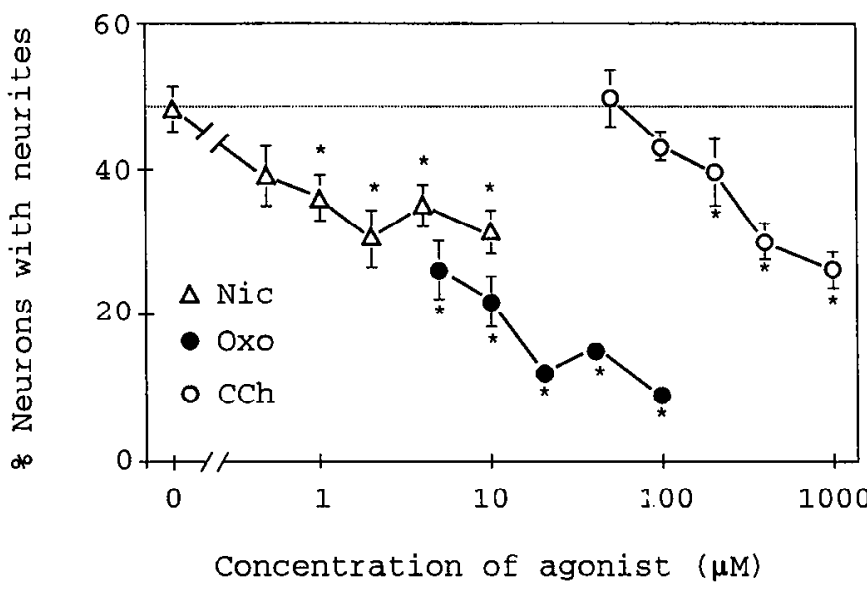

Figure 4. Effect of cholinergic receptor agonists on neurite outgrowth from chick sympathetic neurons. Figure shows the percentage of neurons bearing neurites as a function of the concentration of three cholinergic agonists nicotine ( $\mathrm{Nic})$, oxotremorine $(\mathrm{OxO})$, and carbamylcholine $(\mathrm{CCh})$. The concentration range for cach drug was chosen to be similar to the known concentration range for receptor activation. Data are expressed as the mean value $( \pm$ SEM) obtained from four culture wells in which the percentage of cells bearing neurites greater than $20 \mu \mathrm{m}$ was measured. *, points representing mean values that are significantly different from control values without inhibitor $(P<0.05)$.

To address the question of whether the neurite outgrowthpromoting activity was associated with the AChE itself, or with a undetected trace contaminant, HPLC-purified AChE was further subjected to immunoaffinity chromatography on a column of protein A-Sepharose to which was coupled an anti-AChE IgG1 monoclonal antibody (PAS-AE1). To control for nonspecific adsorption of proteins onto the column, a similar column

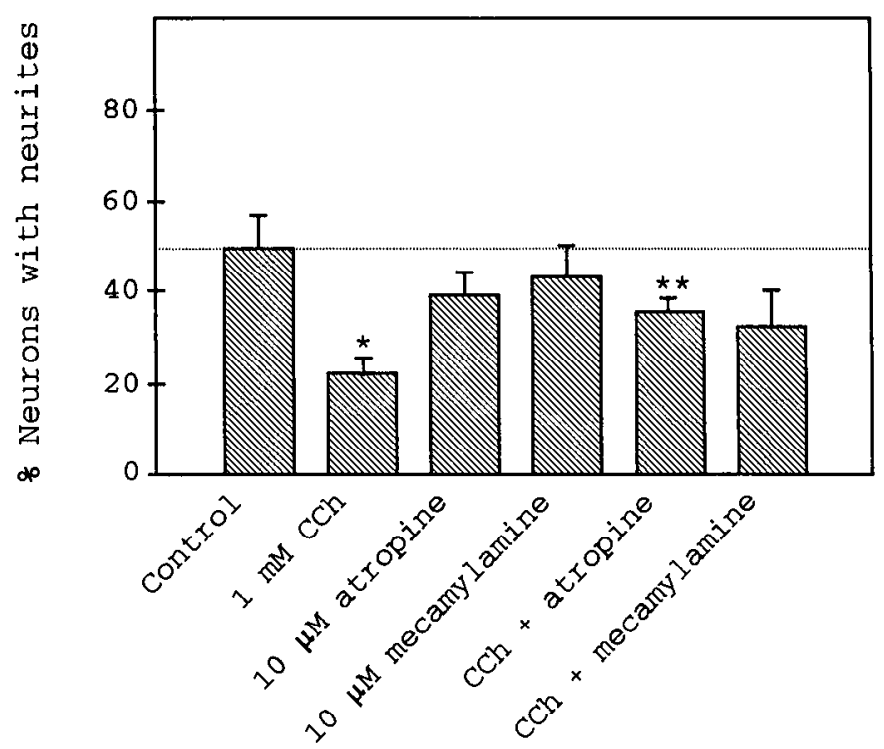

Figure 5. Effect of $\mathrm{CCh}$ and the cholinergic receptor antagonists atropine $(10 \mu \mathrm{M})$ and mecamylamine $(10 \mu \mathrm{M})$ on the percentage of neurons bearing neurites. Data are expressed as the mean value ( \pm SEM) obtained from four culture wells in which the percentage of neurons bearing neurites greater than $20 \mu \mathrm{m}$ was measured. ${ }^{*}$, significantly different $(P$ $<0.05)$ from control values as assessed using a Student's $t$ test; ${ }^{* *}$, significantly different $(P<0.05)$ from incubations with $\mathrm{CCh}$ alone as assessed using a Student's $t$ test. The significance of the drug effects was also confirmed from a one-way ANOVA. 


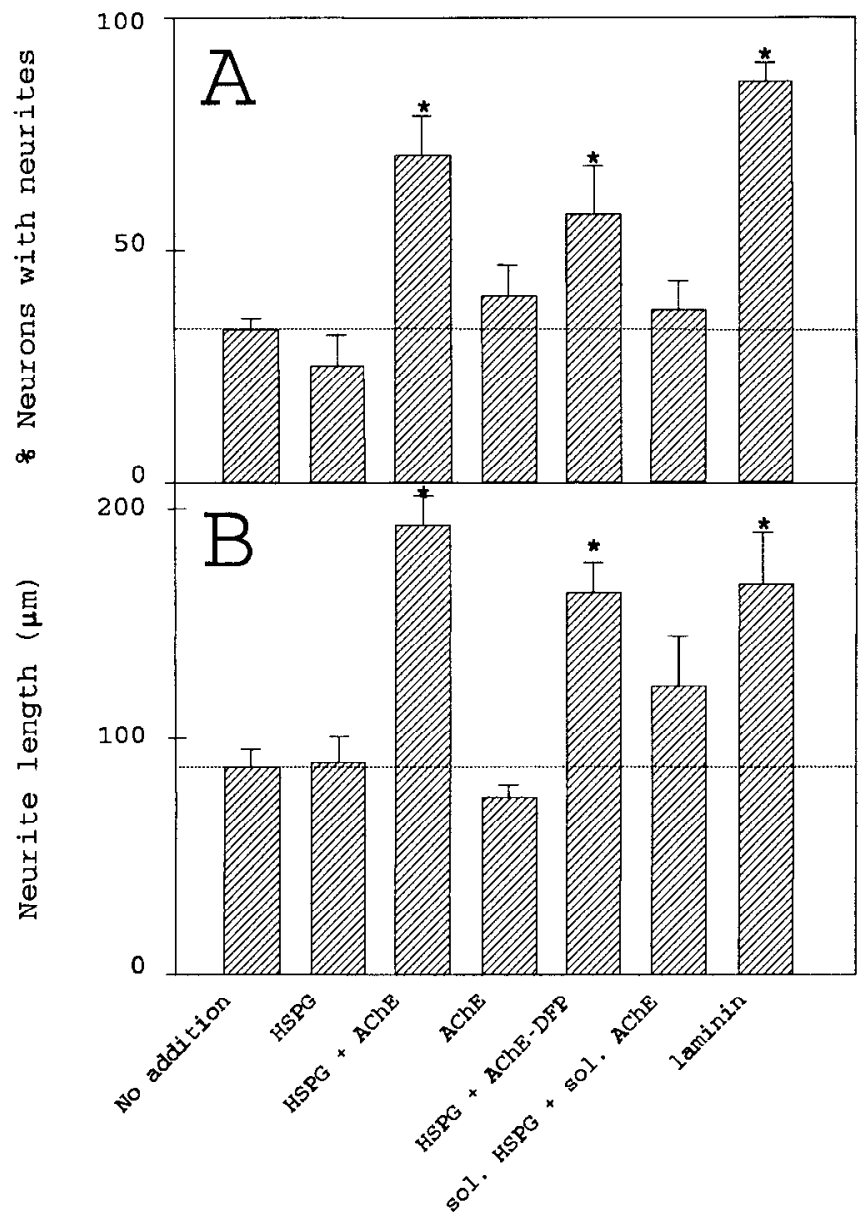

Figure 6. Effect of substratum-bound HSPG, AChE or laminin on neurite outgrowth from chick sympathetic neurons. Culture dishes (24well) were coated with $100 \mu \mathrm{g} / \mathrm{ml}$ of polylysine, followed by either 10 $\mu \mathrm{g} / \mathrm{ml}$ of HSPG and $/$ or AChE or $10 \mu \mathrm{g} / \mathrm{ml}$ of laminin. The percentagc of neurons bearing neurites $(A)$ and the neurite length $(B)$ in each treatment group are shown. In some of the incubations, the AChE solution $(10 \mu \mathrm{g} / \mathrm{ml})$ was first incubated with $150 \mu \mathrm{M}$ diisopropylfluorophosphate $(D F P)$ for $30 \mathrm{~min}$ at room temperature to produce an enzymically inactive form of AChE ( $A C h E-D F P)$. In other incubations, the AChE and HSPG were added in soluble form (sol. $H S P G+$ sol. $A C h E$ ) at the time the cells were plated. Data are expressed as the mean value $( \pm$ SEM) obtained from four culture wells. *, significantly different from the control value (neurite outgrowth in the presence of polylysine alone) as determined using a Student's $t$ test.

was constructed using a nonspecific IgG1 antibody (clone NN18) directed against an intracellular neurofilament antigen, which would not be expected to interfere with an extracellular function of $\mathrm{AChE}$ in the neurite outgrowth-promotion assay. The eluate from each column was then tested for its effects on neurite outgrowth (Table 2). Only the eluate from the PAS-AE I column, containing affinity-purified AChE, stimulated neurite outgrowth.

The stimulatory effect of $\mathrm{AChE}$ on neurite outgrowth was not restricted to sympathetic neurons. We also examined the effect of substratum-bound HSPG and AChE on neurite outgrowth from cultures of chick brain neurons. Very similar results were obtained (Fig. 7). Again, AChE and HSPG failed to stimulate neurite outgrowth on their own. However, when neurons were cultured on substrates of both AChE and HSPG, neurite outgrowth was significantly stimulated. As for the sympathetic neu-
Table 2. Effect of precoating culture dishes with various protein fractions on neurite outgrowth

\begin{tabular}{lcl} 
Treatment & $\begin{array}{l}\text { AChE } \\
\text { activity } \\
\text { (units/ml) }\end{array}$ & $\begin{array}{l}\text { \% Neurons } \\
\text { with } \\
\text { neurites }\end{array}$ \\
\hline P'lys & & $18 \pm 6$ \\
P'lys + HSPG & & $34 \pm 11$ \\
P'lys + HSPG + PAS-AE1 eluate & $1.6 \pm 0.1$ & $77 \pm 10 \dagger$ \\
P'lys + HSPG + PAS-NN18 eluate & $<0.1$ & $32 \pm 11$ \\
Laminin & & $48 \pm 12$
\end{tabular}

HPLC-purified AChE was incubated with a gel consisting of protein A-Sepharose (PAS) coupled to either an anti-AChE monoclonal IgGl antibody (clone AE1) or a nonspecific $\mathrm{IgGl}$ antibody (clone NN18) directed against an intracellular protein (neurofilament subunit). The bound protein from each fraction was eluted with $3.5 \mathrm{M} \mathrm{MgCl}_{2}$ and the eluate assayed for AChE activity. An identical volume of PAS-NN18 eluate and PAS-AE1 eluate was used for precoating culture dishes in the neurite outgrowth assay. Table shows the concentration of AChE in units $/ \mathrm{ml}$ used to coat each well. Values are means \pm SEM $(n=4)$. P'lys, polylysine.

* Significantly different from PAS-NN1 8 eluate $(p<0.05)$.

$\dagger$ Significantly different from P'lys + HSPG treatment group $(p<0.05)$

ronal cultures, the effect of AChE and HSPG in combination was comparable to that of laminin.

\section{Discussion}

This study provides direct evidence that $\mathrm{ACh}$ is involved in the regulation of neurite outgrowth from cultures of dissociated chick sympathetic neurons. In this regard, the study supports the work of previous studics (Hohmann et al., 1988; Lipton et al., 1988; Mattson, 1988; Lipton and Kater, 1989; Lauder, 1993) suggesting a role for $\mathrm{ACh}$ in neurite outgrowth and neuronal

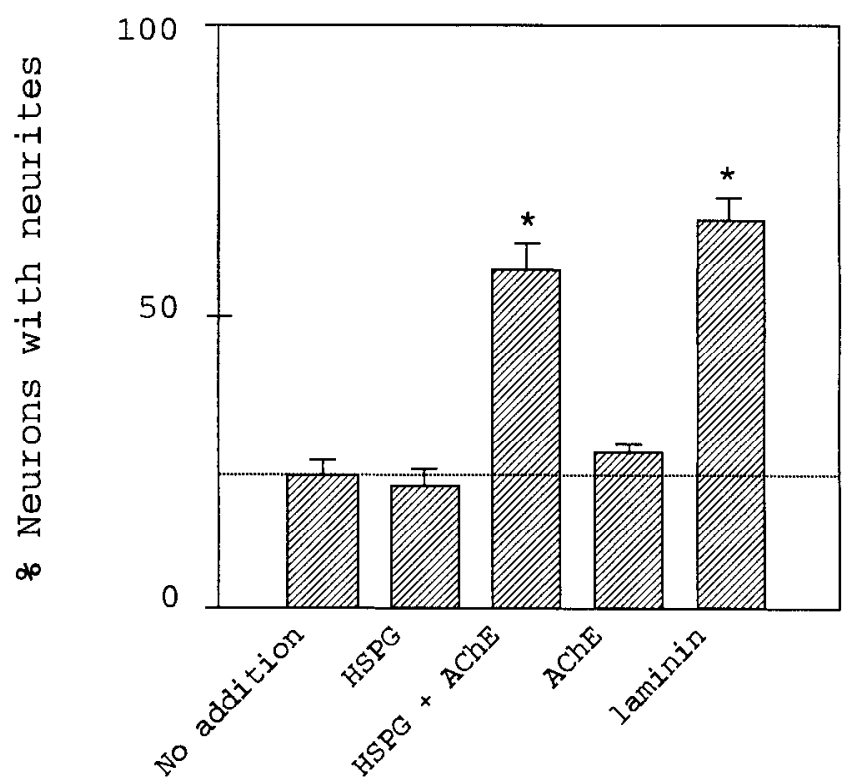

Figure 7. Effect of substratum-bound HSPG, AChE, or laminin on neurite outgrowth from E1 2 chick brain neurons. Culture dishes were coated with $100 \mu \mathrm{g} / \mathrm{ml}$ polylysine, followed by either $10 \mu \mathrm{g} / \mathrm{ml}$ of IISPG and/or AChE or $10 \mu \mathrm{g} / \mathrm{ml}$ laminin. The neurons were cultured for $2 \mathrm{~d}$ in the presence of DMEM containing $10 \%$ fetal calf serum. Figure shows the percentage of neurons bearing neurites. Values are means \pm SEM obtained from four culture wells in which approximately 100 randomly selected neurons were counted in each well (five fields of 20 neurons/ field). *, aignificantly different from incubations containing no HSPG or AChE 
differentiation. In addition, this study demonstrates that AChE, the enzyme that degrades $\mathrm{ACh}$, may also be involved in the regulation of neurite outgrowth, and that it may promote neurite outgrowth by two distinct mechanisms. The first mechanism involves inactivation of $\mathrm{ACh}$, whereas the second mechanism involves a noncatalytic function.

Our results provide an explanation for the spatiotemporal association of $\mathrm{AChE}$ expression with neurite outgrowth that has been observed in previous studies (Robertson, 1987; Layer et al., 1988, 1991, 1992, 1993; Robertson et al., 1988; Layer, 1991; Small et al., 1992). The expression of AChE occurs long before the onset of synaptogenesis (Layer, 1991), suggesting that the function of AChE expressed during neurite outgrowth is unrelated to its classic role in neurotransmission. Our own studies show that AChE expression is increased in the chick brain between E6 and E9 (Small et al., 1992). This period coincides with the major phase of neurite outgrowth in the chick brain. In other studies, transient AChE expression has been noted in developing rat thalamocortical neurons during the stage when axons are rapidly growing into cortical layer IV before making synaptic contact with cortical neurons (Robertson, 1987). The association of AChE with neurite processes has been observed in several systems, including chick sympathetic neurons in culture (Rotundo and Carbonetto, 1987).

One mechanism whereby AChE may regulate neurite outgrowth is by preventing the inhibitory actions of $\mathrm{ACh}$ on neurite outgrowth. There is evidence from other studies that $\mathrm{ACh}$ is synthesized prior to synaptogenesis (Filogamo and Marchisio, 1971; Silver, 1974) and that it may regulate physiological processes including neurite outgrowth (Mattson, 1988). Like AChE, the expression of ChAT (the enzyme that synthesizes $\mathrm{ACh}$ ) is correlated with morphogenic changes in cells occurring prior to the onset of synaptogenesis (Schambra et al., 1989). In the mouse forebrain, ChAT appears in mitotic cells of the germinal zone of the olfactory lateral and third ventricles as early as embryonic day 13.5 (Schambra et al., 1989). In the chick sympathetic ganglion, ChAT activity rises sharply between E6 and E8, in parallel with the expression of AChE (Filogamo and Marchisio, 1971). $\mathrm{ACh}$ has been reported to inhibit neurite outgrowth from rat retinal ganglion cells (Lipton et al., 1988) and chick retina (Lankford et al., 1988) and to inhibit dendrite outgrowth from rat hippocampal pyramidal cells (Mattson, 1988).

Studies by Lipton et al. (1988) have shown that mecamylamine can stimulate neurite outgrowth, demonstrating a nicotinic receptor-mediated mechanism regulating neurite outgrowth. The present study suggests that muscarinic receptors may also regulate neurite outgrowth from chick sympathetic neurons. The muscarinic receptor agonist oxotremorine was a potent inhibitor of neurite outgrowth. Furthermore, the muscarinic receptor antagonist atropine partially blocked the action of $\mathrm{CCh}$ on neurite outgrowth. Sympathetic neurons possess both muscarinic and nicotinic receptors (Appenzeller, 1990). Muscarinic receptors on cell bodies mediate both slow IPSPs (Horn and Dodd, 1981) and slow EPSPs (Adams, 1982) in certain postganglionic neurons, whereas nicotinic receptors mediate only fast EPSPs (Jan and Jan, 1983). It is not known whether all of these receptor types are also expressed on the neurites of E12 chick sympathetic neurons in culture. Although nicotine exerted only a weak inhibitory action on neurite outgrowth, this does not imply that the nicotinic effect might be less important in vivo. It is well established that nicotinic receptors rapidly desensitize in vitro (Deneris et al., 1991). Thus the relatively poor effect of nicotine over a $24 \mathrm{hr}$ incubation period might be the result of the desensitization of the nicotinic receptors under the culture conditions. The observation that $\mathrm{CCh}$ possessed a weaker agonist effect than oxotremorine was interesting. It is possible that stimulation of nicotinic receptors by $\mathrm{CCh}$ might desensitize not only the nicotinic response, but also the muscarinic response, hence the greater potency of a pure muscarinic agonist such as oxotremorine.

The mechanism whereby cholinergic receptors might regulate neurite outgrowth is unknown. Studies by Kater and coworkers (reviewed by Lipton and Kater, 1989) have shown that intracellular $\mathrm{Ca}^{2+}$ can have strong influences on process outgrowth. Activation of both nicotinic and muscarinic receptors in sympathetic ganglia stimulates $\mathrm{Ca}^{2+}$ entry through voltage-gated calcium channcls (Adams, 1982; Jan and Jan, 1983).

The present study provides evidence that AChE can also stimulate neurite outgrowth through a noncatalytic mechanism. The evidence for this can be summarized as follows. First, complete inhibition of the esterase activity by DFP failed to abolish the neurite outgrowth promoting effect. Second, soluble AChE (even when present in excess over that used for the substratum-bound studies) failed to stimulate neurite outgrowth. This result indicates that the esteratic activity of $\mathrm{AChE}$ is not per se sufficient for the neurite outgrowth effect. Third, neither mecamylamine nor atropine stimulated neurite outgrowth in the absence of $\mathrm{CCh}$. Thus, the effect of substratum-bound AChE is unlikely to be related to the inactivation of endogenously produced $\mathrm{ACh}$, as inactivation of cholinergic receptors would have been expected to have a similar effect on neurite outgrowth. Fourth, substratum-bound HSPGs were also required to demonstrate the effect of $\mathrm{AChE}$ on neurite outgrowth, suggesting that therc is a synergistic interaction between HSPGs and AChE. As the binding of HSPG to AChE does not influence the enzyme's catalytic activity (data not shown), this suggests that some noncatalytic function is involved.

Although a protease is associated with certain preparations of cholinesterases from different sources (Chubb et al., 1980, 1983; Lockridge, 1982; Chatonnet and Masson, 1985; Checler and Vincent, 1989; Michaelson and Small, 1993), it is highly unlikely that a contaminating protease activity is responsible for the neurite outgrowth-promoting effects that we have observed. The final purification procedure for $\mathrm{AChE}$ involves ionexchange HPLC, a step that easily separates the protease activity from the esterase (Michaelson and Small, 1993). No contaminating proteins were detected either in the amino acid sequence analysis or upon gel electrophoresis. In addition, the neurite outgrowth-promoting activity was recovered with the $\mathrm{AChE}$ fraction following further purification by immunoaffinity chromatography.

The view that $\mathrm{AChE}$ can promote neurite outgrowth through a noncatalytic mechanism is consistent with previous studies. The amino acid sequence of AChEs and butyrylcholinesterases has been found to be homologous to two Drosophila proteins, neurotactin and glutactin, which mediate heterologous cell adhesion (Barthalay et al., 1990; de la Escalera et al., 1990; Olson et al., 1990). In addition, certain isoforms of AChE may possess an HNK-1 epitope that is commonly found on cell adhesion proteins (Bon et al., 1987). Studies by Layer et al. (1993) suggest on the basis of enzyme inhibitor experiments that cholinesterases can regulate neurite outgrowth from chick tectal cell cullures. In our own studies (Table 1), we found that the AChE inhibitor edrophonium weakly inhibited neurite outgrowth. This 
effect may be related to a noncatalytic action of the drug similar to that described by Layer et al (1993) for other AChE inhibitors.

The requirement for HSPG in the neurite outgrowth-promoting effect of AChE is similar to that seen for several other proteins. For example, the functions of neurite outgrowth-promoting molecules such as glia-derived nexin (Wallace et al., 1988) and the amyloid protein precursor of Alzheimer's disease (Small et al., 1994) can be stimulated through an interaction with heparin or HSPG. Although asymmetric (collagen-tailed) forms of $\mathrm{AChE}$ are known to bind strongly to heparin and are thought to interact with HSPG through the collagen-like "tail" subunit, there is also evidence that globular AChEs may bind with heparin or HSPG (Ramírez et al., 1990).

The observation that $\mathrm{AChE}$ has actions that are unrelated to neurotransmission may help to explain the localization of $\mathrm{AChE}$ in regions that are not normally considered to be cholinoceptive. Of interest in this regard is the observation that AChE is localized to the regions of amyloid plaques in the brains of patients with Alzheimer's disease. The presence of AChE around plaques is thought to be unrelated to the degeneration of cholinergic neurons (Mesulam and Geula, 1988; Schatz et al., 1990; Ulrich et al., 1990). It is interesting to note that AChE is coordinately expressed with the Alzheimer's APP in the developing chick brain (Small el al., 1992). Furthermore, both proteins promote neurite outgrowth and show a similar dependence for the presence of HSPGs in this action (Small et al., 1994). It is possible that the deposition of $\mathrm{AChE}$ in amyloid deposits in the Alzheimer's disease brain may be related to some underlying defect in APP metabolism. The identification and correction of such a defect could have therapeutic implications.

\section{References}

Adams P (1982) Voltage-dependent conductances of vertebrate neurones. Trends Neurosci 5:116-119.

Appenzeller O (1990) The autonomic nervous system. An introduction to basic and clinical concepts, pp 131-255. Amsterdam: Elsevier.

Barthalay Y, Hipeau-Jacquotte R, de la Escalera S, Jiménez F, Piovant M (1990) Drosophila neurotactin mediates heterophilic cell adhesion. EMBO J 9:3603-3609.

Birdsall NJM, Burgen ASV, Hulme EC (1978) The binding of agonists to brain muscarinic receptors. Mol Pharmacol 14:723-736.

Bon S, Méflah K, Musset F, Grassi J, Massoulié J (1987) An immunoglobulin $\mathrm{M}$ monoclonal antibody, recognizing a subset of acetylcholinesterase molecules from electric organ of Electrophorus and Torpedo, belongs to the HNK-1 anti-carbohydrate family. J Neurochem 49:1720-1731.

Chatonnet A, Masson P (1985) Study of the peptidasic site of cholinesterase: preliminary results. FEBS Lett 182:493-498.

Checler F, Vincent JP (1989) Peptidasic activities associated with acetylcholinesterase are due to contaminating enzymes. J Neurochem 53:924-928.

Chubb IW, Hodgson AJ, White GH (1980) Acetylcholinesterase hydrolyzes substance P. Neuroscience 5:2065-2072.

Chubb IW, Ranieri E, White GH, Hodgson AJ (1983) The enkephalins are amongst the peptides hydrolyzed by purified acetylcholinesterase. Neuroscience 10:1369-1377.

de la Escalera S, Bockamp EO, Moya F, Piovant M, Jiménez F (1990) Characterization and gene cloning of neurotactin, a Drosophila transmembrane protein related to cholinesterases. EMBO J 9:3593-3601.

Deneris ES, Connolly J, Rogers SW, Duvoisin R (1991) Pharmacological and functional diversity of neuronal nicotinic acetylcholine receptors. Trends Pharmacol Sci 12:34-40.

Ellman GL, Courtney KD, Andres V Jr, Featherstone RM (1961) A new and rapid colourimctric detcrmination of acetylcholinesterase activity. Biochem Pharmacol 7:88-95.

Filogamo G, Marchisio PC (1971) Acetylcholine system and neural development. Neurosci Res 4:29-64.

Hadházy P, Szerb JC (1977) The effect of cholinergic drugs on
[ $\left.{ }^{3} \mathrm{H}\right]$ acctylcholine release from slices of rat hippocampus, striatum and cortex. Brain Res 123:311-322.

Hohmann CF, Brooks AR, Coyle JT (1988) Neonatal lesions of the basal forebrain cholinergic neurons result in abnormal cortical development. Dev Brain Res 42:253-264.

Horn JP, Dodd J (1981) Monosynaptic muscarinic activation of $\mathrm{K}^{+}$ conductance underlies the slow inhibitory postsynaptic potential in sympathetic ganglia. Nature 292:625-627.

Jan YN, Jan LY (1983) A LHRH-like peptidergic neurotransmitter capable of "action at a distance" in autonomic ganglia. Trends Neurosci 6:320-325.

Lankford KL, DeMello FG, Klein WL (1988) D,-type dopamine receptors inhibit growth cone motility in cultured retina neurons: evidence that neurotransmitters act as morphogenic growth regulators in the developing central nervous system. Proc Natl Acad Sci USA $85: 2839-2843$

Lauder JM (1993) Neurotransmitters as growth regulatory signals: role of receptors and second messengers. Trends Neurosci 16:233-240.

Layer PG (1991) Cholinesterases during development of the avian nervous system. Cell Mol Neurobiol 11:7-33.

Layer PG, Kaulich S (1991) Cranial nerve growth in birds is preceded by cholinesterase expression during neural crest cell migration and the formation of an HNK-1 scaffold. Cell Tissue Res 265:393-407.

Layer PG, Alber R, Rathjen FG (1988) Sequential activation of butyrylcholinesterase in rostral half somites and acetylcholinesterase in motoneurones and myotomes preceding growth of motor axons. Development 102:387-396.

Layer PG, Weikert T, Willbold E (1992) Chicken retinospheroids as developmental and pharmacological in vitro models: acetylcholinesterase is regulated by its own and by butyrylcholinesterase activity. Cell Tissue Res 268:409-418.

Layer PG, Weikert T, Alber R (1993) Cholinesterases regulate neurite growth of chick nerve cells in vitro by means of a non-enzymatic mechanism. Cell Tissue Res 273:219-226.

Lipton SA, Kater SB (1989) Neurotransmitter regulation of neuronal outgrowth, plasticity and survival. Trends Neurosci 12:265-270.

Lipton SA, Frosch MP, Phillips MD, Tauck DL, Aizenman E (1988) Nicotinic antagonists enhance process outgrowth by rat retinal ganglion cells in culture. Science 239:1293-1296.

Lockridge $O$ (1982) Substance $P$ hydrolysis by human serum cholinesterase. J Neurochem 39:106-110.

Mattson MP (1988) Neurotransmitters in the regulation of neuronal cytoarchitecture. Brain Res Rev 13:179-212.

McCobb DP, Cohan CS, Connor JA, Kater SB (1988) Interactive effects of serotonin and acetylcholine on neurite elongation. Neuron $1: 377-385$

Mesulam MM, Geula C (1988) Acetylcholinesterase-rich pyramidal neurons in the human neocortex and hippocampus: absence at birth, development during the life span, and dissolution in Alzheimer's disease. Ann Neurol 24:765-773.

Michaelson S, Small DH (1993) A protease is recovered with a dimeric form of acetylcholinesterase in fetal bovine serum. Brain Res 611: $75-80$.

Olson PF, Fessler LI, Nelson RE, Sterne RE, Campbell AG, Fessler JH (1990) Glutactin, a novel Drosophila basement membrane-related glycoprotein with sequence similarity to serine esterases. EMBO J 9:1219-1227.

Ralston JS, Rush RS, Doctor BP, Wolfe AD (1985) Acetylcholinesterase from fetal bovine serum. Purification and characterization of soluble G4 enzyme. J Biol Chem 260:4312-4318.

Ramírez G, Barat A, Fernández HL (1990) Interaction of asymmetric and globular acetylcholinesterase species with glycosaminoglycans. J Neurochem 54:1761-1768.

Robertson RT (1987) A morphogenic role for transiently expressed acetylcholinesterase in thalamocortical development? Neurosci Lett $75: 259-264$.

Robertson RT, Yu J (1993) Acetylcholinesterase and neural development: new tricks for an old dog? News Physiol Sci 8:266-272.

Robertson RT, Höhmann CF, Bruce JL, Coyle JT (1988) Neonatal enucleations reduce specific activity of acetylcholinesterase but not choline acetyltransferase in developing rat visual cortcx. Dev Brain Res 39:298-302.

Rotundo RL, Carbonetto ST (1987) Neurons segregate clusters of membrane-bound acetylcholinesterase along their neurites. Proc Natl Acad Sci USA 84:2063-2067. 
Schambra UB, Sulik KK, Petrusz P, Lauder JM (1989) Ontogeny of cholinergic neurons in the mouse forebrain. J Comp Neurol 288:101122.

Schatz CR, Geula C, Mesulam M (1990) Competitive substrate inhibition in the histochemistry of cholinesterase activity in Alzheimer's disease. Neurosci Lett 117:56-61.

Silver A (1974) The biology of cholinesterases. Amsterdam: Elsevier.

Small DH, Nurcombe V, Moir R, Michaelson S, Monard D, Beyreuther K, Masters CL (1992) Association and release of the amyloid protein precursor of Alzheimer's disease from chick brain extracellular matrix. J Neurosci 12:4143-4150.

Small DH, Michaclson S, Marley PD, Friedhuber A, Hocking A, Livett BG (1993) Regulation of acetylcholinesterase secretion from per- fused bovine adrenal gland and isolated bovine chromaffin cells. J Auton Nerv Syst 42:131-142.

Small DH, Nurcombe V, Reed G, Clarris H, Moir R, Beyreuther K, Masters CL (1994) A heparin-binding domain in the amyloid protein precursor of Alzheimer's disease is involved in the regulation of neurite outgrowth. J Neurosci 14:2117-2127.

Ulrich J, Meier-Ruge W, Probst A, Meier E, Ipsen S (1990) Senile plaques: staining for acetylcholinesterase and A4 protein: a comparative study in the hippocampus and entorhinal cortex. Acta Neuropathol (Berl) 80:624-628.

Wallace A, Rovelli G, Hofsteenge J, Stone SR (1989) Effect of heparin on the glia-derived nexin-thrombin interaction. Biochem J 257:191196. 